\section{STATEMENT RELATIVE TO A CASE OF HYDRO- PHOBIA CURED BY CHLOROFORM.}

To the Editor of ThE LANCET.

Sir,-In reply to your correspondent of the 9 th September, $I$ beg to state that $I$ have made every inquiry touching the questions suggested by him as to the time which had elapsed between the bite of the cat and the manifestation of the disease, and find that it was ten years and a few months; but the labourer in question, being a very illiterate man, is not able to give the exact date.

He states positively that he could not have received the poison in any other way at any subsequent period. The cat had strayed from its home about two miles, and was amongst some gooseberry bushes in a garden where he was working at the time it flew at him; that it was foaming at the mouth, and would not let go its hold until it was killed by his brother, who was at work with him.

The cat had previously bit three children and one dog. The children were all subjected to the actual cautery, and (so far as he knows) all escaped the disease; but he left the country shortly afterwards, and, consequently, knows nothing of them for several years. The dog died of hydrophobia. I am, Sir, your obedient servant, Rich. Yates Ackerley.

Prince Edwin-street, Liverpool, Sept. 21st, 1818 .

\section{POULTICES AND PILINE. "What's in a name."-SHAKESPEARE. To the Editor of The LanceT.}

Str,-Permit me to make a remark or two on the criticisms of M. Velpean's use of poultices by a writer in your last number, who informs us that he is the inventor of the "spongio-piline."

M. Velpeau, it may be presumed, prefers poultices to sponges or layers of lint, because he has found them more useful, and otherwise deserving preference. Thin sponges, or sliced sponge covered with oil-cloth, were at one time much used in France; and between these and the "spongio-piline" there is the same difference with respect to heat-retaining power, that exists between a blue coat and a black one; no greater than exists probably between an advertised vessel for cooking potatoes, which its ingenious inventor has called the anhydro hepseterion, and other ordinary means. A hard or ridiculous name, though it may bring pence to the pocket of the patentee does not change the nature of things.

Poultices are superior to sponges and other similar means, not only by retaining more heat, but, in many cases, by com bining an useful support. None of these expedients preserve the heat long, which, as $M$. Velpeau says, is soon transferred to the body; but it is obvious that by covering the poultice with oil-cloth, the moisture can be retained by it as well as by a sponge.-I am, Sir, yours very obediently,

Sept. 25th, 1848

COMMON-SENSE AND HONESTY.

\section{WEIGHT OF THE HUMAN BRAIN.} To the Editor of The LANCET.

Sir, $-I$ observe in a late number of The LANCEx a reference by a correspondent to a statement contained in my work on Cholera, respecting the weight of the brain of an European soldier, as compared with the weight of Cuvier's brain. My weights are all expressed in avoirdupois, as appears from the letters "Av:" inserted opposite this very case. The weights your correspondent cites from Tiedemann are in Troy. If he will take the trouble to reduce the one into the other, he will find that the two weights nearly agree. Thus the Troy ounce contains 480 grains, and the Troy pound 5760 . The avoirdupois ounce contains 437.5 grains, and the pound 7000 . The grains of both are alike. The weights of the brains (that is to say, the entire encephalon) of Cuvier and Dupuytren, expressed in grains, are respectively 28,590 and 27,840 . In my case the weight of the cerebrim alone is 27,555 , and the weight of the encephalon 29,106 .

I have taken the weights cited by your correspondent, without referring to Tiedemann, but of course they are correct I was, however, under the impression that the weight of Cuvier's brain was sixty-three ounces av., which is exactly equal to that of the cerebrum in my observation.

My case is certainly a very singular one, not merely on account of the large size of the cerebrum, but on account of the small size of the cerebellum, and of the disproportion thence induced in the relative weights of these organs to each other.
If the relative weight of the cerebellum to the cerebrum may be considered as 1 to 7.5 or 8 , in the case under discussion the proportion undergoes the extraordinary alteration of 1 to 18 .

I am, Sir, your most obedient servant,

Upper Seymour-street, PortmanE. A. Parkes.

square, Sent. 30th, 1848.

MEDICAL FEES AT ASSURANCE OFFICES. To the Editor of Tue Laycet.

Sin,-Deeming it important that the assurance offices which refuse to remunerate medical men for their services should be known to the profession, I send the following facts to you, the well-known advocate of our just rights, and have the honour to subscribe myself, Sir, yours, \&c.,

Sept. 23rd, 1848 .

St. JoHN W. Lucas.

Early in this month, Mr, - applied to the Equitable Assurance Company, to effect an assurance on his life, and referred the directors to me, as the medical man able to give them the information they required; in consequence of which $I$ received the following printed form, which I enclose:-

Equitable Assurance Office

Near Blackfriars.bridze, Sept. 7 th, 1848.

SIR,-The directors of this Society, having been referred to you for an account of the present and general state of health of $\mathrm{Mr}$. , will be obliged to you for such information respecting his constitution and general manner of living as shall enable them to determine on the safety and propriety of assuring his life in this office.-I am, with the compliments of the directors, Sir, your obedient servant,

St. John Wells Lucas, Esq.

Arthur Morgan, Actuary.

(COPY OF REPLX.)

Louth, Lincolnshire, Sept. 8th, 1848.

SIR,-I shall have great pleasure in giving you the information you require, respecting the health of Mr. - , on receiving from you the usual professional fee of $£ 11 s$.

Of late years it has been too much the habit of assurance offices to expect a medical man to give a professional opinion without remuneration, forgetting that both his time and his talents are concerned in the inquiry.

Arthur Morgan, Esq.

I am, Sir, your obedient servant

ST. JoHN W. Lucas.

After the lapse of a few days, the party applying to the Society wrote to inform me that he had received a letter from the Equitable Office, requesting him to furnish the company with the name of some other medical man who knew the state of his health. I therefore despatched the following to the secretary of the office in question.

Louth, Sept, 12th, 1848 .

Srr,-Mr. - informs me that you desire to be furnished with the name of some other medical man who knows the state of his health. As the purpose of the Equitable Office is evidently to evade paying a fee for a professional opinion, I have recommended Mr. - to insure in an office which respects the just claim of medical men to remuneration in these cases. $\quad I$ am, Sir, your obedient servant, Arthur Morgan, Esq. ST. JoHN W. LuCas.

To the Editor of The LavoET.

SIR,-I take the liberty of forwarding a copy of a correspondence which took place between the secretary of an assurance office and your obedient servant, Sept. 26th, 1848.

Edward Gibgon.

Eagle and Protector Life Association, 3 , Crescent, Bridge-street.

Sir, - A proposal having been made to the directors of this Association to effect an assurance on the life of Mr. - and reference given to you for information as to his present and general health, I am desired by him to request that you will favour them by answering, at your earliest convenience, the several questions on the annexed half-sheet.

I have also to inform you that your communication will be considered by the directors as strictly confidential.

I am, Sir, your very obedient, humble servant, Cuarles Jelicicok, Actuary and Secretary.

Mr. - will oblige the directors by answering the following questions respecting the health and constitution(Here follow the questions by which the directors are to be obliged.) 